\title{
Controlling Surface-Induced Nanocomposites by Lipoplexes for Enhanced Gene Transfer
}

\author{
Bingbing Sun ${ }^{1}$ and Hong Shen ${ }^{2}$ \\ ${ }^{1}$ Department of Chemical Engineering, University of Washington, P.O. Box 351750, Seattle, WA 98195, USA \\ ${ }^{2}$ Elsa Biologics, LLC, P.O. Box 25725, Seattle, WA 98165, USA \\ Correspondence should be addressed to Hong Shen; hong.shen@elsa-biologics.com
}

Received 10 September 2015; Accepted 25 October 2015

Academic Editor: Antonio Villaverde

Copyright (c) 2015 B. Sun and H. Shen. This is an open access article distributed under the Creative Commons Attribution License, which permits unrestricted use, distribution, and reproduction in any medium, provided the original work is properly cited.

\begin{abstract}
Surface-induced biomineralization represents a flexible approach to immobilizing DNA onto biomaterial surfaces for surfacemediated DNA delivery. Immobilized naked DNA is uniformly embedded in thin films of nanocomposites, which limits the internalization of DNA to some cell types, such as neuronal cells. In this study, DNA molecules were initially complexed with liposomes to form lipoplexes. Subsequently, these lipoplexes were immobilized onto a cell culture compatible surface through surface-induced biomineralization. Under all the conditions we examined, lipoplexes were efficiently immobilized onto the surface and formed lipoplex-nanocomposites. We have shown that the size of liposomes and the composition of mineralizing solutions have significant effects on the morphology and topology of nanocomposites and thus the organization and the intracellular levels of DNA. The transgene expression mediated by lipoplex-nanocomposites was greatly enhanced in neuronal cells compared to the immobilized naked DNA.
\end{abstract}

\section{Introduction}

Delivering genetic materials to mediate functions of cells present in tissue engineering scaffolds holds great promise for regenerative medicine. Systemic gene transfer approaches are unable to deliver genes across the barriers of tissue scaffolds and thus limit the availability of DNA to cells. Surfacemediated DNA delivery, which provides a highly localized level of DNA for cells, possesses great potential to direct cell functions on tissue engineering scaffolds while supporting cell growth [1-3].

A number of approaches have been developed to enable surface-mediated gene delivery. DNA molecules are either directly immobilized onto surfaces by coprecipitating with calcium phosphate $[4,5]$ or first complexed with dendrimers [6-8], cationic polymers [9-11], or liposomes $[1,12,13]$ and then immobilized onto biomaterial surfaces through electrostatic interactions. Up to 27\% DNA immobilization efficiency has been obtained by the aforementioned methods [1, 14]; and, in the presence of extracellular matrix (ECM) proteins, the efficiency has been increased up to $80 \%$ [11]. Surfaceinduced biomineralization represents a flexible approach to immobilizing DNA onto substrates [15-18]; the immobilization efficiency has been shown to be nearly $100 \%$ regardless of the composition of mineralizing solutions $[15,17]$. More importantly, the level of transgene expression can be easily tuned by manipulating the composition of mineralizing solutions with respect to individual cell types $[15,17,18]$. However, the internalization of DNA is cell type-dependent. A low level of cellular DNA uptake mediated by surface-induced nanocomposites has been observed in several cell types such as neuronal cells and breast cancer cells [17]. When naked DNA is immobilized by surface-induced biomineralization, DNA is embedded in a continuous thin film of nanocomposites. The morphology and topology result in strong binding between nanocomposites and biomaterial surfaces, which limits the effective release of DNA for internalization by cells. Therefore, we hypothesized that controlling the morphology and topology of surface-induced nanocomposites would improve the internalization of DNA by cells and thus enhance the level of transgene expression.

DNA and cationic liposomes are often rapidly selfassembled as supramolecular structures. Depending on the type of liposomes, the ratio of DNA to liposomes, and 
the complexation duration, several structures, including multilamellar structure with alternating lipid bilayer and DNA monolayers [19], columnar inverted hexagonal structures [20], and spaghetti-meatball assemblies [21], have been observed. Lipid monolayers and vesicles have been used as templates for the induction of mineralization in solutions [22, 23]. We reason that these supramolecular structures can be used as templates to control the morphology and topology of surface-induced nanocomposites. A recent study has shown that lipoplexes formed from DNA and commercially formulated Lipofectamine 2000 can be incorporated into nanocomposites that are induced in a solution mimicking a simulated body fluid [24].

In this study, by using liposomes made of a widely used cationic lipid, 1,2-dioleoyl-3-trimethylammonium-propane (DOTAP), and six different mineralizing solutions (Table 1), we systematically examined the effects of the size of liposomes and the charge ratio of DNA to cationic lipids on the morphology and topology of surface-induced nanocomposites of different compositions, the distribution and cellular uptake of DNA, and gene transfer efficiency. We did not choose the commercially available lipids, Lipofectamine 2000, since we had no information on the composition of lipids. The DNA/DOTAP complexes, or lipoplexes, were immobilized onto plasma-treated polystyrene surfaces through surfaceinduced biomineralization. The nanocomposites containing lipoplexes are called lipoplex-nanocomposites in comparison with DNA-nanocomposites doped with naked DNA. The cellular DNA uptake, gene transfer efficiency, and cell viability mediated by lipoplex-nanocomposites were subsequently examined by using a model neuronal cell line, B35 cells. Potentially, the as-developed DNA/DOTAP complexes could be used in bone tissue engineering to promote fracture healing and bone growth where peripheral innervation is needed [25].

\section{Materials and Methods}

2.1. Cell Culture. B35 cells were cultured in Dulbecco's Modified Eagle Media (DMEM), supplemented with 10\% fetal bovine serum (FBS) and $2 \mathrm{mM}$ of L-glutamine. The cells were maintained in an incubator at $37^{\circ} \mathrm{C}$ and $5 \% \mathrm{CO}_{2}$.

2.2. DOTAP Liposome Preparation. A given amount of chloroform solution of DOTAP $(10 \mathrm{mg} / \mathrm{mL})$ was placed in a glass tube and the chloroform was evaporated under a stream of argon gas. For the direct-mixing method, which has been used by previous studies [26-28], the lipid film was resuspended at $2 \mathrm{mg} / \mathrm{mL}$ in Dulbecco's phosphate buffered saline (D-PBS) at room temperature and then directly used for the complexation with DNA. For the freeze-thaw-extrusion method, the lipid film was resuspended at $2 \mathrm{mg} / \mathrm{mL}$ in HEPES-buffered saline (20 mM HEPES, $150 \mathrm{mM} \mathrm{NaCl}$, pH 7.4) and incubated at $43^{\circ} \mathrm{C}$ for $1 \mathrm{~h}$. The resulting solution was subjected to freeze- $\left(-196^{\circ} \mathrm{C}\right)$ thaw $\left(40^{\circ} \mathrm{C}\right)$ cycles for 10 times and then passed through the extruder (Avanti Polar Lipids, Alabaster, AL) with a polycarbonate membrane filter (100 and $1000 \mathrm{~nm}$ ) five times before the complexation with DNA.
TABLE 1: Formulations of mineralizing solutions.

\begin{tabular}{lcccccc}
\hline Concentration $(\mathrm{mM})$ & $\mathrm{A}$ & $\mathrm{B}$ & $\mathrm{G}$ & $\mathrm{H}$ & $\mathrm{G}-\mathrm{Sr}$ & $\mathrm{G}-\mathrm{F}$ \\
\hline $\mathrm{CaCl}_{2} \cdot 2 \mathrm{H}_{2} \mathrm{O}$ & 2.5 & 3.7 & 2.5 & 2.5 & 2.5 & 2.5 \\
$\mathrm{KH}_{2} \mathrm{PO}_{4}$ & 1 & 1 & 1 & 1 & 1 & 1 \\
$\mathrm{NaCl}$ & 141 & 141 & 141 & 141 & 141 & 141 \\
$\mathrm{KCl}$ & 4 & 4 & 4 & 4 & 4 & 4 \\
$\mathrm{MgSO}_{4} \cdot 6 \mathrm{H}_{2} \mathrm{O}$ & 0.5 & 0.5 & 0 & 0.5 & 0 & 0 \\
$\mathrm{MgCl}_{2} \cdot 6 \mathrm{H}_{2} \mathrm{O}$ & 1 & 1 & 0 & 5 & 0 & 0 \\
$\mathrm{NaHCO}_{3}$ & 4.2 & 4.2 & 4.2 & 4.2 & 4.2 & 4.2 \\
$\mathrm{SrCl}_{2}$ & 0 & 0 & 0 & 0 & 3 & 0 \\
$\mathrm{NaF}$ & 0 & 0 & 0 & 0 & 0 & 3 \\
\hline
\end{tabular}

2.3. Size and Stability Measurements. The sizes of liposomes and lipoplexes were examined using Zetasizer Nano ZS (Malvern Instruments, Westborough, MA). The measurements were carried out at $25^{\circ} \mathrm{C}$ in the indicated solution. The size change with the time was used to evaluate the stability of liposomes and lipoplexes.

2.4. Topology of Lipoplex-Nanocomposites on Substrates. Atomic force microscopy (AFM) was used to determine the topology of lipoplex-nanocomposites on substrates. AFM images were taken using tapping mode with a Veeco Dimension 3100 (Center for Nanotechnology, University of Washington) and a FESP silicon probe. A scan rate of $1.4 \mathrm{~Hz}$ was used with an integral gain of 0.4 and proportional gain of 0.8 . The images were analyzed using NanoScope (Veeco, Plainview, NY).

2.5. DNA Complexation Efficiency. $25 \mu \mathrm{L}$ of pcDNA3LDHC4 $(1 \mu \mathrm{g} / \mathrm{mL})$ was mixed with $100 \mu \mathrm{L}$ of $1: 500$ dilution of Quant-iT PicoGreen dsDNA reagent (Invitrogen, Carlsbad, CA) for $5 \mathrm{~min}$. The resulting solution was then mixed with $25 \mu \mathrm{L}$ of $12 \mu \mathrm{g} / \mathrm{mL}$ DOTAP liposomes to yield DNA to DOTAP ratio of $1: 12(\mathrm{w} / \mathrm{w})$. As the DNA was complexed with liposomes, the fluorescence intensity decreased. The fluorescence change of the resulting solution at $520 \mathrm{~nm}$ was recorded (excitation wavelength: $480 \mathrm{~nm}$ ) using a SpectraMax M5 microplate reader (Molecular Devices, Sunnyvale, CA). Controls, including DNA and liposomes only in the presence or absence of dye, were also included to take into account the change of fluorescence due to the prolonged incubation of dye with DNA and photobleaching, interference from liposomes themselves, and light scattering. Both liposomes and DNA in the absence of PicoGreen did not exhibit detectable emission at $520 \mathrm{~nm}$. PicoGreen did not directly interact with liposomes, resulting in detectable emission. The amount of DNA complexed with DOTAP was calculated by subtracting the free DNA remaining in the solution from the total DNA added to the solution.

2.6. Surface Induction of DNA- or Lipoplex-Nanocomposites. The process of inducing nanocomposites on cell culture surface has been developed previously [15]. Briefly, one milliliter of mineral solutions (Table 1) with different formulations was mixed with $1 \mu \mathrm{g}$ of DNA either in the form of naked DNA 
(10 $\mu \mathrm{L}$ of $100 \mu \mathrm{g} / \mathrm{mL}$ DNA in Tris-EDTA) or DNA/DOTAP complexes (lipoplexes, $20 \mu \mathrm{L}$ in Milli-Q water). The mixtures were added to each well of 24-well tissue culture plates (BD Biosciences, San Jose, CA). The mineralization was conducted at $37^{\circ} \mathrm{C}$ in a humid incubator for $8 \mathrm{~h}$. The remaining mineral solution was removed, and surface-induced DNAor lipoplex-nanocomposites were washed using cell culture media before seeding cells. We did wash the deposited DNA/ lipid complexes after mineralization and before seeding cells. This means the remaining precipitated complexes were removed if there are any, and, after seeding cells on top of DNA/DOTAP complexes, the cells were transfected by the immobilized complexes exclusively. The resulting nanocomposites were named after the respective mineralizing solution shown in Table 1.

\subsection{Quantification of the DNA Deposition Efficiency. During} the course of mineralization, $50 \mu \mathrm{L}$ of the supernatant in each well was sampled and assayed for the DNA concentration by Quant-iT PicoGreen dsDNA reagent (Invitrogen, Carlsbad, CA) following the manufacturer's protocol. The amount of DNA precipitated was calculated by subtracting the amount of DNA remaining in the supernatants from the total DNA added. The standard curve was constructed by using lipoplexes formed under the same conditions as those used for mineralization to take into account the effect of complexation on the fluorescent intensity. DNA or lipoplexes in D-PBS were included as a control and incubated at $37^{\circ} \mathrm{C}$ as samples for mineralization. The concentration of DNA before and after the incubation was tested. There was no DNA or lipoplexes bound to the sides of wells in the absence of mineralizing solutions.

2.8. Solubility of Nanocomposites in Extracellular Environment. The release of calcium from nanocomposites was used to evaluate the solubility. Mineralization was carried out for $8 \mathrm{~h}$. The amount of calcium precipitated on the surface was then determined by subtracting the calcium that remained in the solution from the initial calcium added to the wells. Then, $500 \mu \mathrm{L}$ of tissue culture medium was directly placed on the surface deposited with DNA- and lipoplex-nanocomposites at $37^{\circ} \mathrm{C}$ and $5 \% \mathrm{CO}_{2} .24 \mathrm{~h}$ later, calcium released from nanocomposites was determined using a modified colorimetric method based on complex formation with orthocresolphthalein [29]. The percentage (\%) of calcium released was determined by normalizing the calcium released against the amount of calcium precipitated on the surface.

2.9. DNA Organization on the Surface Deposited with Nanocomposites. Fluorescein isothiocyanate- (FITC-) labeled DNA (2.7 kb) (Mirus Bio, Madison, WI) was used. DNAor lipoplex-nanocomposites were fabricated as above. DNA distribution was examined with a $20 \mathrm{x}$ objective by a Nikon TE 2000 inverted microscope. Images were acquired with a CoolSNAP ES2 charge-coupled camera (Photometrics; Tucson, AZ). The surface plot of the fluorescence intensity of FITC-labeled DNA was generated by ImageJ (National Institute of Health).
2.10. Size and Morphology of Lipoplex-Nanocomposites. Scanning electron microscope was used to examine the size and morphology of surface-induced nanocomposites. The samples were sputter-coated with $12 \mathrm{~nm}$ of platinum using a SPI Sputter Sputter Coater (Structure Probe, Inc.; West Chester, PA) and were analyzed with a JEOL 7000 SEM with a beam voltage of $10 \mathrm{kV}$ (Electron Microscopy Center, University of Washington).

2.11. Gene Transfer. Cells in $500 \mu \mathrm{L}$ of tissue culture medium were directly plated on the surface deposited with DNA- and lipoplex-nanocomposites at the density of $1 \times 10^{5}$ cells per well of a 24 -well tissue culture plate and incubated at $37^{\circ} \mathrm{C}$ and $5 \%$ $\mathrm{CO}_{2}$. The reporter plasmid, gWIZ Beta-gal (Aldevron; Fargo, $\mathrm{ND})$ encoding $\beta$-galactosidase ( $\beta$-gal), was used. $36 \mathrm{~h}$ later, cells were lysed with $150 \mu \mathrm{L}$ of a solution containing $10 \mu \mathrm{M} 2$ ME, $9 \mathrm{mM} \mathrm{MgCl}_{2}$ and $0.1 \%$ triton X-100 in D-PBS for $15 \mathrm{~min}$. Then, three freeze-thaw cycles between $-80^{\circ} \mathrm{C}$ and $37^{\circ} \mathrm{C}$ were performed to ensure the complete release of proteins from cells. $50 \mu \mathrm{L}$ of the lysed cell solution was mixed with $50 \mu \mathrm{L}$ of solution containing $0.15 \mathrm{mM}$ chlorophenol red- $\beta$ D-galactoside (CPRG), $10 \mu \mathrm{M} 2-\mathrm{ME}, 9 \mathrm{mM} \mathrm{MgCl}_{2}$ and $0.1 \%$ triton X-100 in D-PBS and incubated at $37^{\circ} \mathrm{C}$ for $30 \mathrm{~min}$. The absorption was measured at $570 \mathrm{~nm}$ using a SpectraMax M5 microplate reader. The quantity of $\beta$-gal produced by the cells was determined by using a standard curve constructed with known concentrations of $\beta$-gal. Gene transfer efficiency was expressed as ng of $\beta$-gal per mg of total protein. Total protein was measured using the Coomassie protein assay (Biorad; Hercules, CA). Briefly, $5 \mu \mathrm{L}$ of the lysed cell solution was diluted with $5 \mu \mathrm{L}$ of D-PBS and then mixed with $200 \mu \mathrm{L}$ of Coomassie solution. The absorption at $595 \mathrm{~nm}$ was determined with a microplate reader. The quantity of protein was determined by using a standard curve with known concentrations of bovine serum albumin (BSA).

2.12. Quantification of DNA Uptake by Flow Cytometry. $0.5 \mu \mathrm{g}$ of naked FITC-labeled DNA (2.7 kb) (Mirus Bio, Madison, WI $)$ or lipoplexes $(0.5 \mu \mathrm{g}$ of DNA, DNA: DOTAP $=1: 12$ $(\mathrm{w} / \mathrm{w}))$ were immobilized on the surfaces as described above. Cells were cultured on surfaces deposited with DNA- or lipoplex-nanocomposites. $24 \mathrm{~h}$ later, cells were washed with $0.25 \mathrm{~mL}$ of Hank's Balanced Salt Solutions (HBSS). Cells were detached using $250 \mu \mathrm{L}$ of trypsin-EDTA ( $0.1 \%$ trypsin, $0.4 \%$ EDTA $4 \mathrm{Na}$ ) at $37^{\circ} \mathrm{C}$ for $5 \mathrm{~min}$. Cells were then washed twice with FACS (1\% FBS in D-PBS) buffer and analyzed by flow cytometry immediately using a BD FACScan2 (Cell Analysis Facility, Department of Immunology, University of Washington). Trypan blue was used to quench the fluorescence associated with the cell surface. The data was analyzed with FlowJo (Tree Star, Ashland, OR), and the arithmetic mean of fluorescence intensity (MFI) of each sample was determined. The uptake of DNA by cells was expressed as the MFI of cells cultured on DNA- or lipoplex-nanocomposites subtracted with the MFI of cells cultured on cell culture surfaces free of nanocomposites.

2.13. Determination of Metabolic Activity of Cells. Metabolic activity of cells on DNA- or lipoplex-nanocomposites 
was determined using the 3-(4,5-dimethylthiazol-2-yl)-2,5diphenyltetrazolium bromide (MTT) colorimetric method, which is based on the reduction of the MTT into formazan crystals by viable cells. Herring sperm DNA $(1 \mu \mathrm{g} / \mathrm{mL})$ was used for mineralization. Briefly, cells were seeded on surface deposited with DNA/DOTAP or DNA-nanocomposites as above. $36 \mathrm{~h}$ later, $50 \mu \mathrm{L}$ of a $5 \mathrm{mg} / \mathrm{mL}$ aqueous solution of MTT (Sigma, St. Louis, MO) was added to cells and incubated at $37^{\circ} \mathrm{C}$ and $5 \% \mathrm{CO}_{2}$ for an additional $2.5 \mathrm{~h}$. Following centrifugation, the supernatant was removed and $1 \mathrm{~mL}$ dimethyl sulfoxide (DMSO) was added to cells and incubated at $37^{\circ} \mathrm{C}$ for $30 \mathrm{~min}$ to dissolve the formazan crystals. The absorption of each sample at $570 \mathrm{~nm}$ was determined using a microplate reader. The relative cell metabolic viability was calculated by normalizing OD values of each sample to the value of cells on surfaces free of nanocomposites.

2.14. Statistical Analysis. Triplicate samples were included in all the experiments. The values shown were as the means of triplicates. All the experiments were repeated two to three times. Data were shown as means \pm s.e. Statistical significance of differences was determined by the unpaired two-tailed Student's $t$-test.

\section{Results and Discussion}

3.1. Characterization of DNA/DOTAP Lipoplexes. The size and structure of liposomes can potentially affect the size and colloidal stability of lipoplexes and thus the topology and reproducibility of surface-induced nanocomposites. We explored the methods to prepare DOTAP liposomes. Two methods have been examined. In method 1 , called the directmixing method, liposomes were formed by directly mixing dried lipids in aqueous solutions through vortexing. This method has been used in several previous studies [26-28]. It resulted in multilamellar structures. The mean diameter of the DOTAP liposomes was around $1800 \mathrm{~nm}$ with polydispersity index (PdI) of 0.28. Upon the complexation with DNA dissolved in mineralizing solutions, the size of lipoplexes varied dramatically within an incubation period of $60 \mathrm{~min}$. Significant aggregations, indicated by the turbidity, were observed (Figure 1(a)). The aggregation and instability of lipoplexes can potentially affect the reproducibility of surfaceinduced nanocomposites.

In method 2, called freeze-thaw-extrusion method, the liposomes were subjected to freeze-thaw cycles and then passed through filters with pore size of $100 \mathrm{~nm}$ or $1000 \mathrm{~nm}$ in diameter. A number of studies have demonstrated that homogenous populations of unilamellar liposome can be obtained using freeze-thaw procedures [30]. The size of liposomes before the extrusion was $324 \mathrm{~nm}$ in diameter with a PdI of 0.36 . The $1000 \mathrm{~nm}$ filter resulted in liposomes with an average diameter of $257 \mathrm{~nm}$ and PdI of 0.23 , while the $100 \mathrm{~nm}$ filter resulted in liposomes with an average diameter of $129 \mathrm{~nm}$ and PdI of 0.16. After complexation with DNA, the size of lipoplexes increased to around $1500 \mathrm{~nm}$ and $2000 \mathrm{~nm}$ in diameter for liposomes prepared with 100 and $1000 \mathrm{~nm}$ filters, respectively. The lipoplexes were stable in most of the mineral solutions examined (Figures 1(b)-1(c)).
Subsequently, we determined the DNA complexation efficiency of DOTAP liposomes prepared by both methods. Using the direct-mixing method, the complexation efficiency gradually reached $40 \%$ within one hour and then leveled off (Figure $1(\mathrm{~d})$ ). While using the freeze-thaw-extrusion method, DNA molecules were more efficiently complexed with liposomes and 70\% complexation was achieved within one hour for both filter sizes. Based on the colloidal stability of liposomes and lipoplexes as well as the DNA complexation efficiency, we chose the freeze-thaw-extrusion method to prepare liposomes and 15 min complexation duration unless specified for the following studies.

3.2. Characterization of Surface-Induced Lipoplex-Nanocomposites. Initially, we measured the efficiency of immobilization of lipoplexes by surface-induced biomineralization. Regardless of the composition of mineralizing solutions and initial size of DOTAP liposome, nearly $100 \%$ of DNA in the form of lipoplexes was immobilized onto the thin films of nanocomposites within the $8 \mathrm{~h}$ mineralization (Figure 2(a)). Compared to other approaches $[1,11,14]$, surface-induced biomineralization more efficiently immobilized DNA onto the surfaces in the form of either naked DNA or lipoplexes.

Subsequently, we examined whether the incorporation of lipoplexes would change the solubility of nanocomposites at the extracellular environment. The solubility was determined by measuring the calcium release from nanocomposites at given $\mathrm{pH}$ in cell culture medium. At pH 7.4 (extracellular $\mathrm{pH}$ ), the solubility of lipoplex-nanocomposites was similar to that of DNA-nanocomposites for all the mineralizing solutions $(p>0.05$, Figure 2(b)).

Our goal is to control the morphology and topology of nanocomposites so that more DNA molecules are accessible to cells for effective gene transfer. Both SEM (Figure 3(a)) and atomic force microscopy (AFM) (Figure 3(b)) were used to examine the morphology and topology of surface-induced nanocomposites, respectively. For DNA-nanocomposites, A, $\mathrm{B}, \mathrm{H}$, and $\mathrm{G}-\mathrm{Sr}$ formed small clusters with the average size of 50-100 nm, which were organized as a continuous film. In contrast, lipoplex-nanocomposites formed large clusters with an average size of $150-250 \mathrm{~nm}$, which were organized into segregated structures. The roughness of substrates deposited with lipoplex-nanocomposites was statistically significantly higher than that of substrates deposited with DNA-nanocomposites $(p<0.01$, Figure $3(\mathrm{c}))$. For nanocomposites $\mathrm{G}$ and $\mathrm{G}-\mathrm{F}$, lipoplexes resulted in a dramatic morphological change of nanocomposites. When smaller liposomes were used, nanocomposite $\mathrm{G}$ exhibited thickened plate-like structures. In contrast, nanocomposite $\mathrm{G}$ transformed from continuous plate-like structures to segregated spherical structures when larger liposomes were used in the formation of lipoplexes. Nanocomposite G-F transformed from randomly distributed needle-like structures into more uniformly distributed spherical structures. Our results showed that the lipoplexes modulated both morphology and topology of surface-induced nanocomposites.

We subsequently examined the DNA distribution on the surface of substrates using fluorescence microscope. A 3D surface plot of the fluorescence intensity of FITC-labeled 

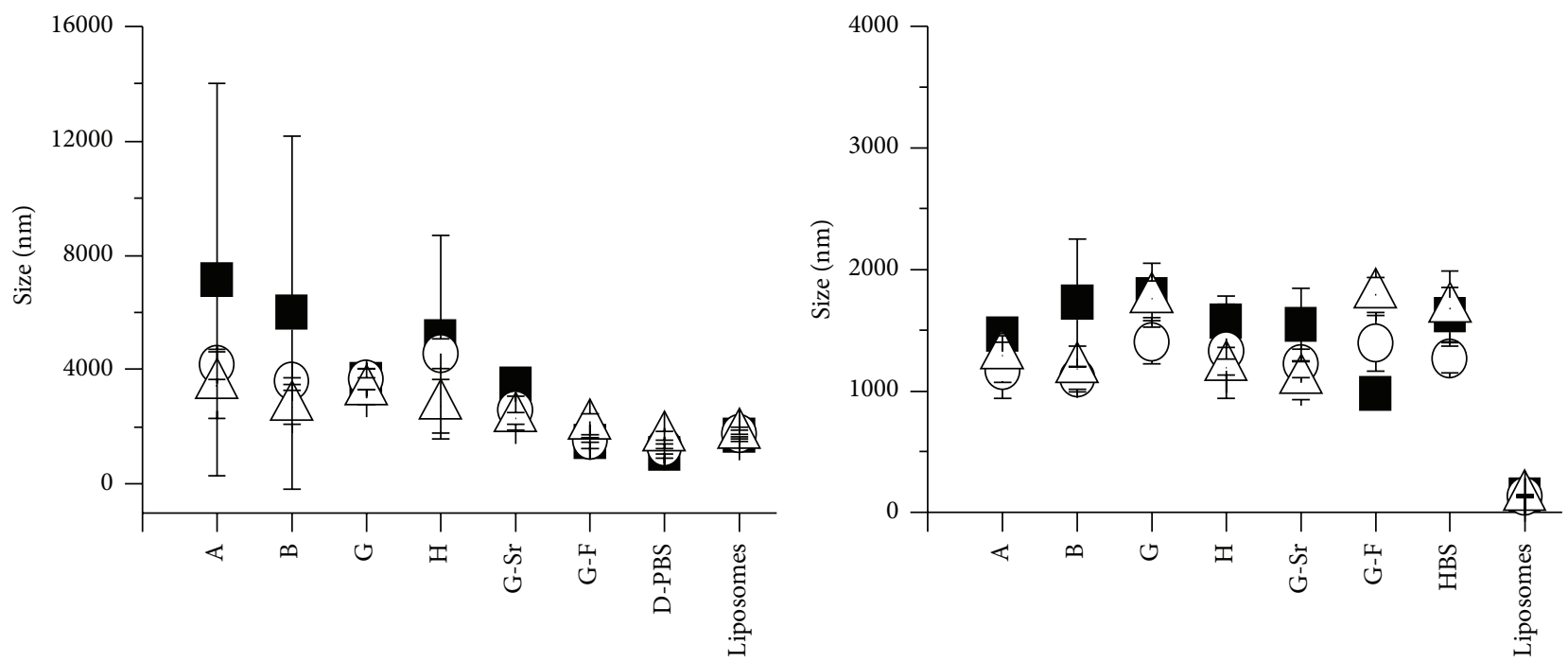

○ $30 \mathrm{~min}$

口 $30 \mathrm{~min}$

$\triangle 60 \mathrm{~min}$

(a)
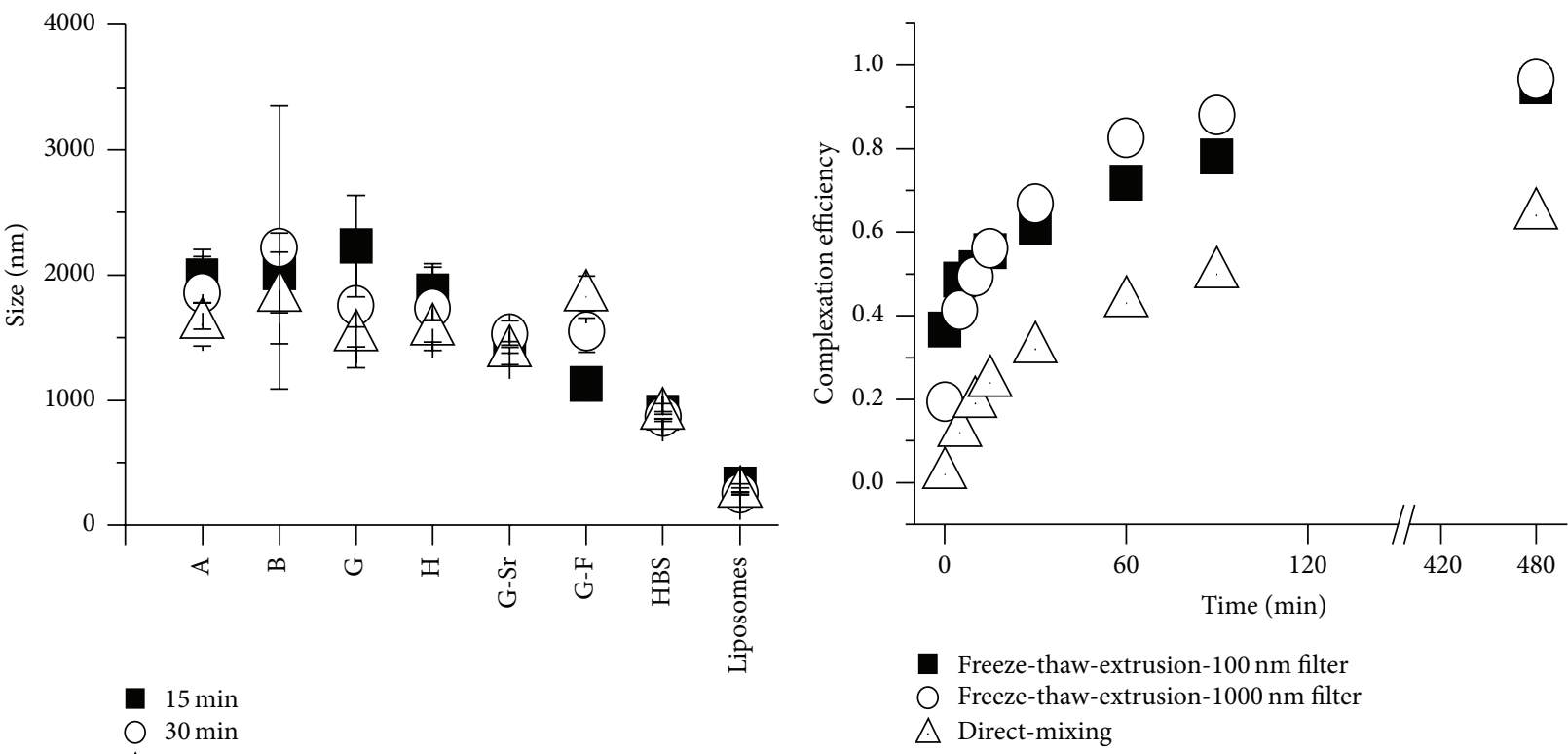

(c)

(d)

FIGURE 1: Characterization of DOTAP liposomes and lipoplexes. The DOTAP liposomes were prepared using the direct-mixing and freezethaw-extrusion methods. Sizes of DOTAP liposomes or lipoplexes prepared by (a) the direct-mixing method and by (b-c) the freeze-thawextrusion method with (b) $100 \mathrm{~nm}$ or (c) $1000 \mathrm{~nm}$ filter. Data were shown as means \pm s.e. (d) DNA complexation efficiency. The DNA : DOTAP ratio was $1: 12(\mathrm{w} / \mathrm{w})$. The time indicates the duration of complexation with DNA.

DNA showed that, for all the mineralizing solutions examined, DNA was organized into discrete depots when lipoplexes were used in the process of mineralization in comparison to the diffused patterns when naked DNA was used (Figure 3(d)). Larger liposomes led to larger discrete depots of DNA. During the preparation of liposomes, the amount of DOTAP and DNA used was kept the same. More lipoplex particles with less DNA molecules per lipoplex were formed using smaller liposomes than larger ones. Therefore, DNA molecules were more localized and segregated on the surface deposited with nanocomposites derived from larger liposomes.

Our results have demonstrated that lipoplexes induce both morphological and topological changes of surfaceinduced nanocomposites but do not change the solubility of nanocomposites. The DNA molecules are organized into discrete depots on surfaces coated with lipoplex-nanocomposites. 


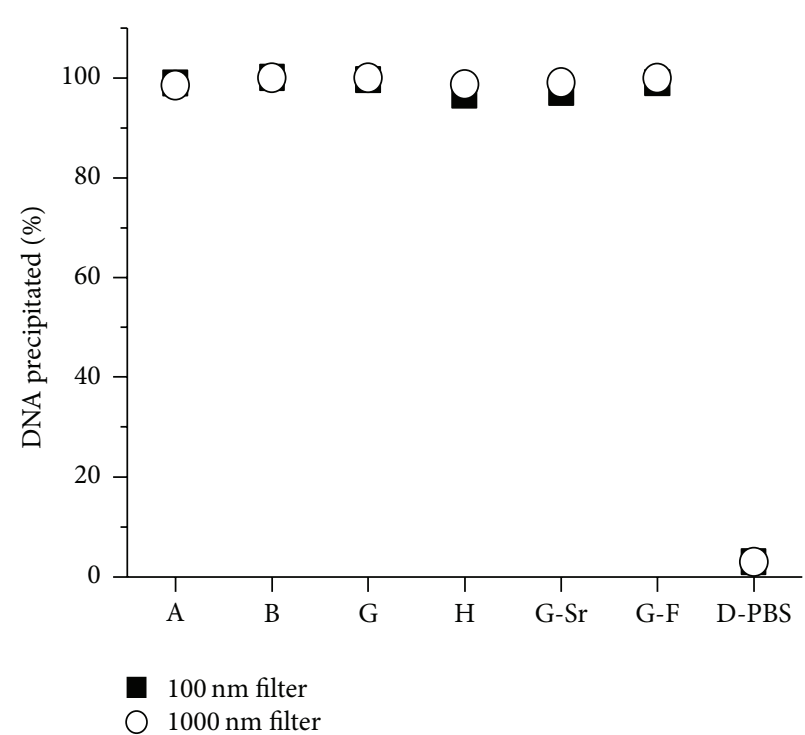

(a)

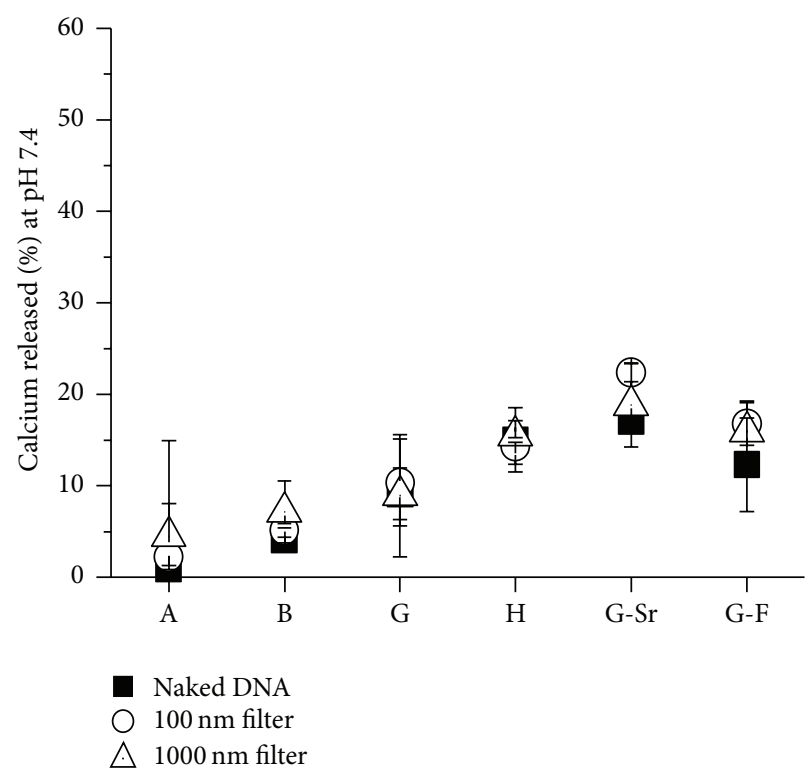

(b)

Figure 2: (a) The DNA immobilization efficiency in the form of lipoplexes by surface-induced biomineralization for $8 \mathrm{~h}$. (b) Calcium release from nanocomposites at $\mathrm{pH}$ 7.4. Nanocomposites were incubated in cell culture medium at $\mathrm{pH} 7.4$ at $37^{\circ} \mathrm{C}$ for $24 \mathrm{~h}$. Data were shown as means \pm s.e. Statistical significance of differences was determined by the unpaired two-tailed Student's $t$-test. The calcium released from lipoplex-nanocomposites was not statistically significantly different compared to that from DNA-nanocomposites $(p>0.05)$.

3.3. Biocompatibility of Lipoplex-Nanocomposites. The morphology and metabolic activity of cells cultured on these surfaces were assessed. Except for formulation G-F, for both sizes of liposomes and most of the mineralizing solutions examined, B35 cells on nanocomposite-deposited surfaces could attach and spread out as well as on surfaces free of nanocomposites (Figure 4(a)). The cells on surfaces coated with lipoplex-nanocomposites exhibited similar metabolic activity as cells on surfaces with DNA-nanocomposites (Figure 4(b)).

As for mineral solution G-F, cells exhibited a statistically significantly lower $(p<0.001)$ metabolic activity when they were cultured on lipoplex-nanocomposites compared to those on DNA-nanocomposites. More detailed studies are required to determine the exact mechanism by which lipoplex-nanocomposite G-F leads to higher level of cytotoxicity. We speculate that the morphological and topological change of nanocomposites can result in an enhanced uptake (Figure 5) of nanocomposites, thus an increase of intracellular $\mathrm{F}^{-}$ion concentration. The $\mathrm{F}^{-}$ion can inhibit enzymes essential for many physiological processes of cells [31]. In addition, the changes in morphology and hydrophobicity of surfaces have also been shown to affect the metabolic activity of cells [32, 33].

3.4. Cellular Uptake of DNA. We hypothesized that controlling the morphology and topology of nanocomposites on biomaterial surfaces to which cells were exposed could potentially enhance the cellular uptake of DNA and thus gene transfer efficiency. Then we examined DNA cellular uptake in neuronal cells, B35. Clearly, for all the nanocomposites and both sizes of liposomes examined, immobilized lipoplexes resulted in 2 to 14 times more cellular uptake of DNA than the immobilized naked DNA (Figure 5). Lipoplexnanocomposites B, H, G-Sr, and G-F resulted in more statistically significant increases of cellular uptake of DNA than biomineral $A$ and $G(p<0.01)$. The initial liposome size also affected the cellular uptake of DNA for lipoplexnanocomposites H, G-Sr, and G-F. Nanocomposites formed from larger liposomes showed a reduced level of cellular uptake of DNA compared to those from smaller liposomes.

DNA was most likely taken up as individual or a cluster of nanocomposites instead of naked DNA or lipoplexes released from the dissolution of nanocomposites. The dissolution of both DNA- and lipoplex-nanocomposites at pH 7.4 (extracellular $\mathrm{pH}$ ) was less than $15 \%$ and similar (Figure 2(b)). A low level of free DNA or lipoplexes was expected in extracellular environment. Therefore, the uptake of DNA would be low if the released DNA or lipoplexes from dissolution of nanocomposites contributed to a significant fraction of DNA uptake. The change of morphology and topology affected the detachment of nanocomposites from the biomaterial surface and dissociation from neighboring clusters, which mostly resulted in the enhanced uptake mediated by lipoplex-nanocomposites. Less lipoplex-nanocomposites were observed than DNA-nanocomposites after they were exposed to cells for $24 \mathrm{~h}$ (Figure 4(a), small dark dots on the surface of cell culture plates).

3.5. Gene Transfer Efficiency. The gene transfer in neuronal cells, B35, mediated by either immobilized lipoplex- or DNAnanocomposites was examined. Compared to immobilized naked DNA, immobilized lipoplex-nanocomposites A, B, G, $\mathrm{H}$, and G-Sr resulted in significantly higher transgene expression (Figure 6). For a given composition of nanocomposites, 

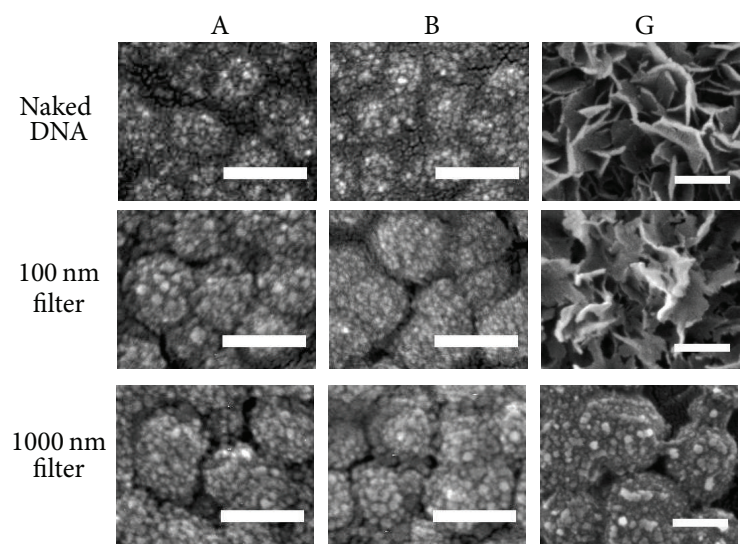
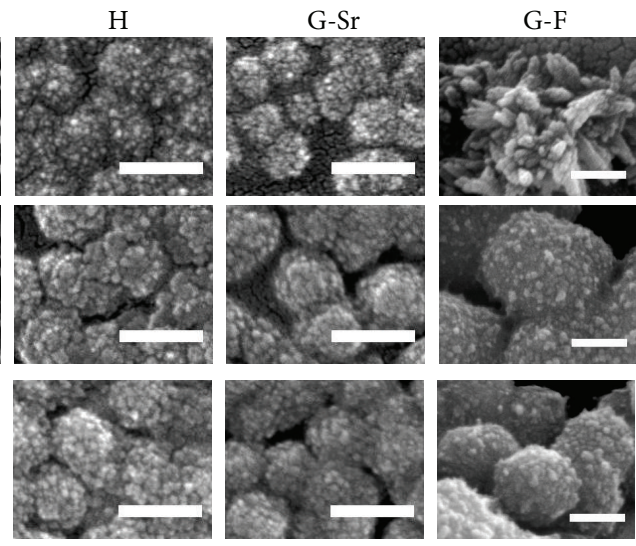

(a)
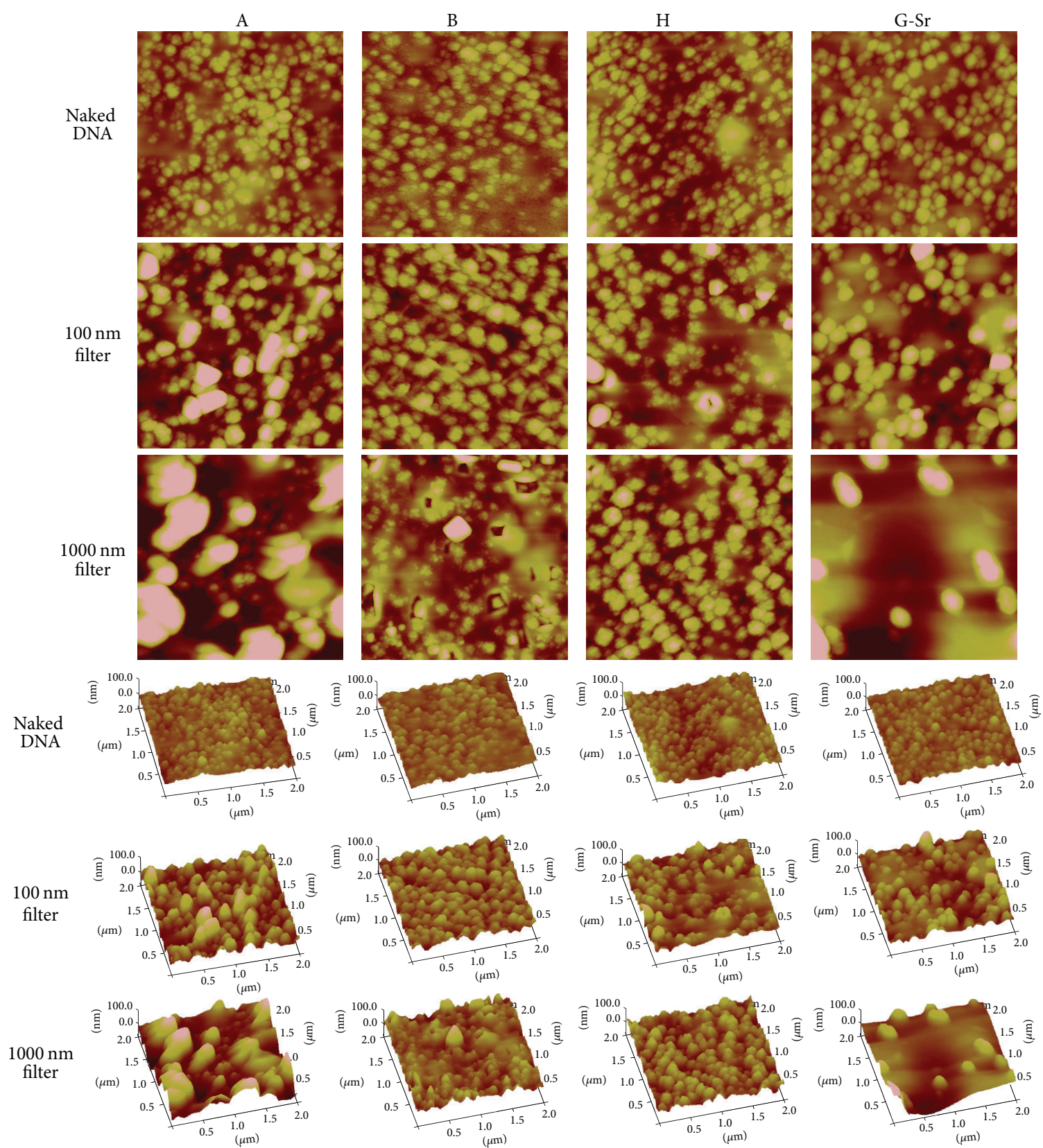

(b)

FIGURE 3: Continued. 


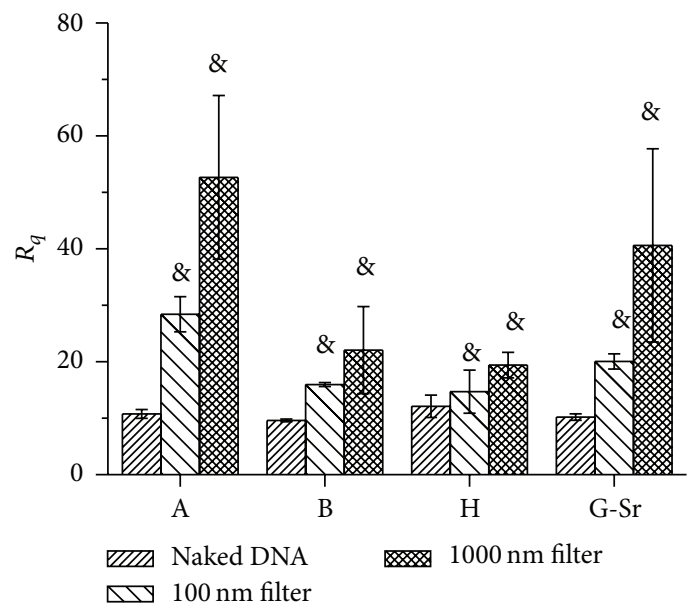

(c)
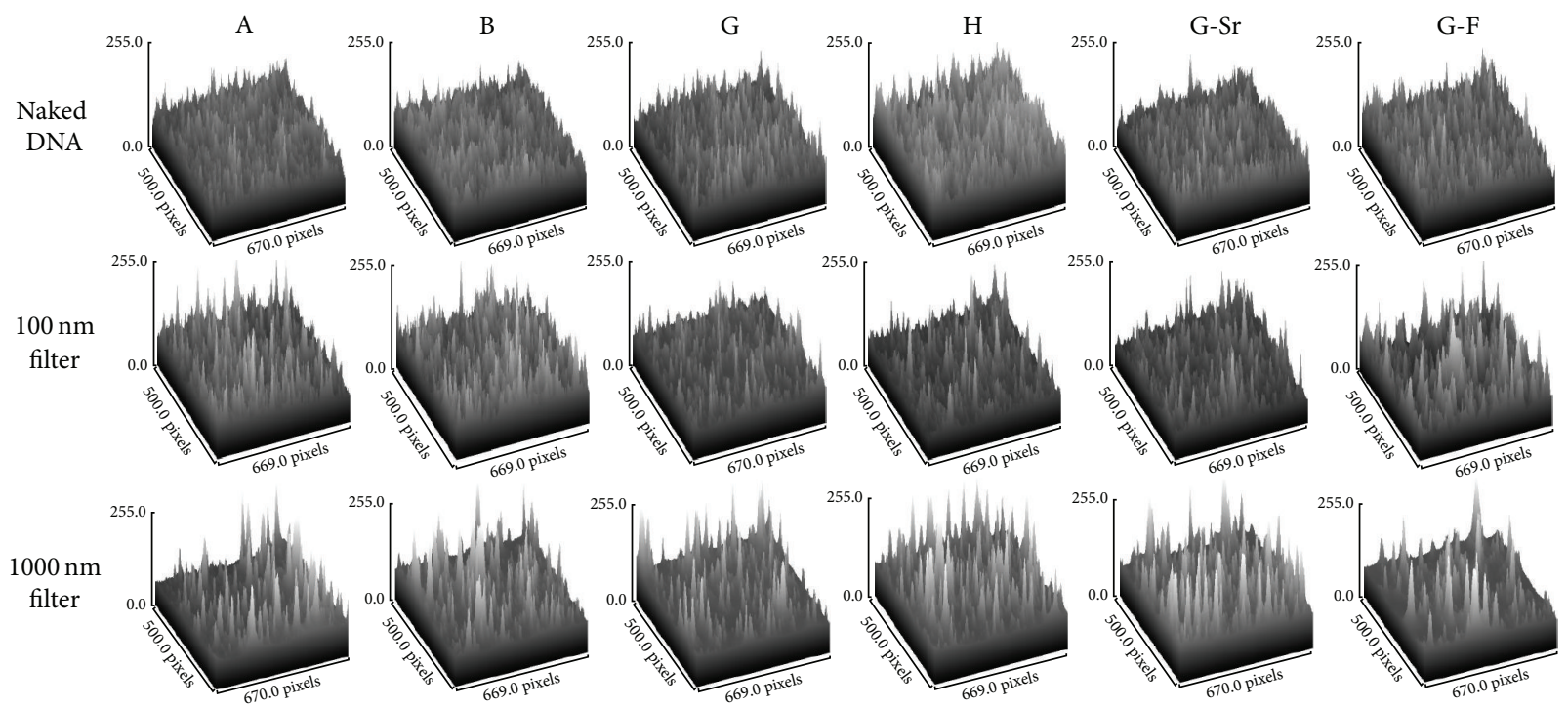

(d)
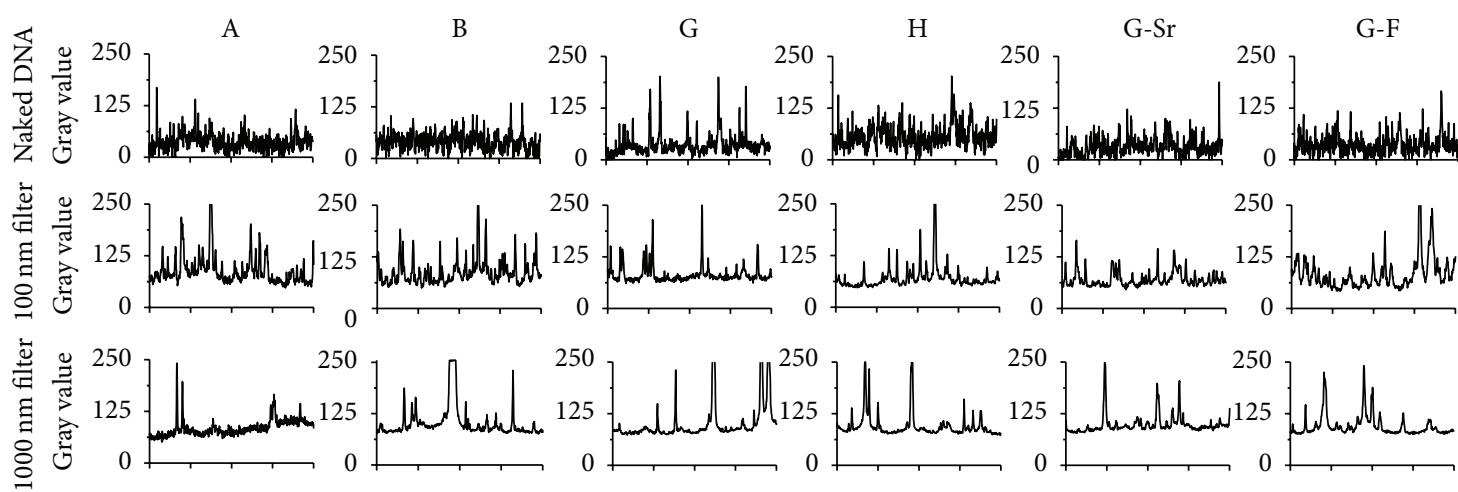

(e)

FIGURE 3: (a) SEM images of surface-induced nanocomposites formed from the indicated mineralizing solutions. The scale bar is $200 \mathrm{~nm}$. (b) AFM topographic images (top 3 panels) and 3D surface plot (bottom 3 panels) of surface-induced nanocomposites on substrates formed from the indicated formulations. The scan size is $2 \mu \mathrm{m} \times 2 \mu \mathrm{m}$. (c) Surface roughness $\left(R_{q}\right.$, root mean square roughness) of surface-induced nanocomposites on substrates formed from the indicated mineralizing solution. $R_{q}$ was calculated using NanoScope (Veeco, Plainview, NY). Data were shown as means \pm s.e. Statistical significance of differences was determined by the unpaired two-tailed Student's $t$-test. The $R_{q}$ of substrates deposited with lipoplex-nanocomposites was considered statistically significantly different from that with DNA-nanocomposites at ${ }^{\&} p<0.01$. (d) The surface plot of the fluorescence intensity of FITC-labeled DNA on the surfaces deposited with DNA- or lipoplexnanocomposites. (e) The profiles of fluorescent intensity along the diagonal direction determined using ImageJ (National Institute of Health) was used to demonstrate the DNA distribution. 

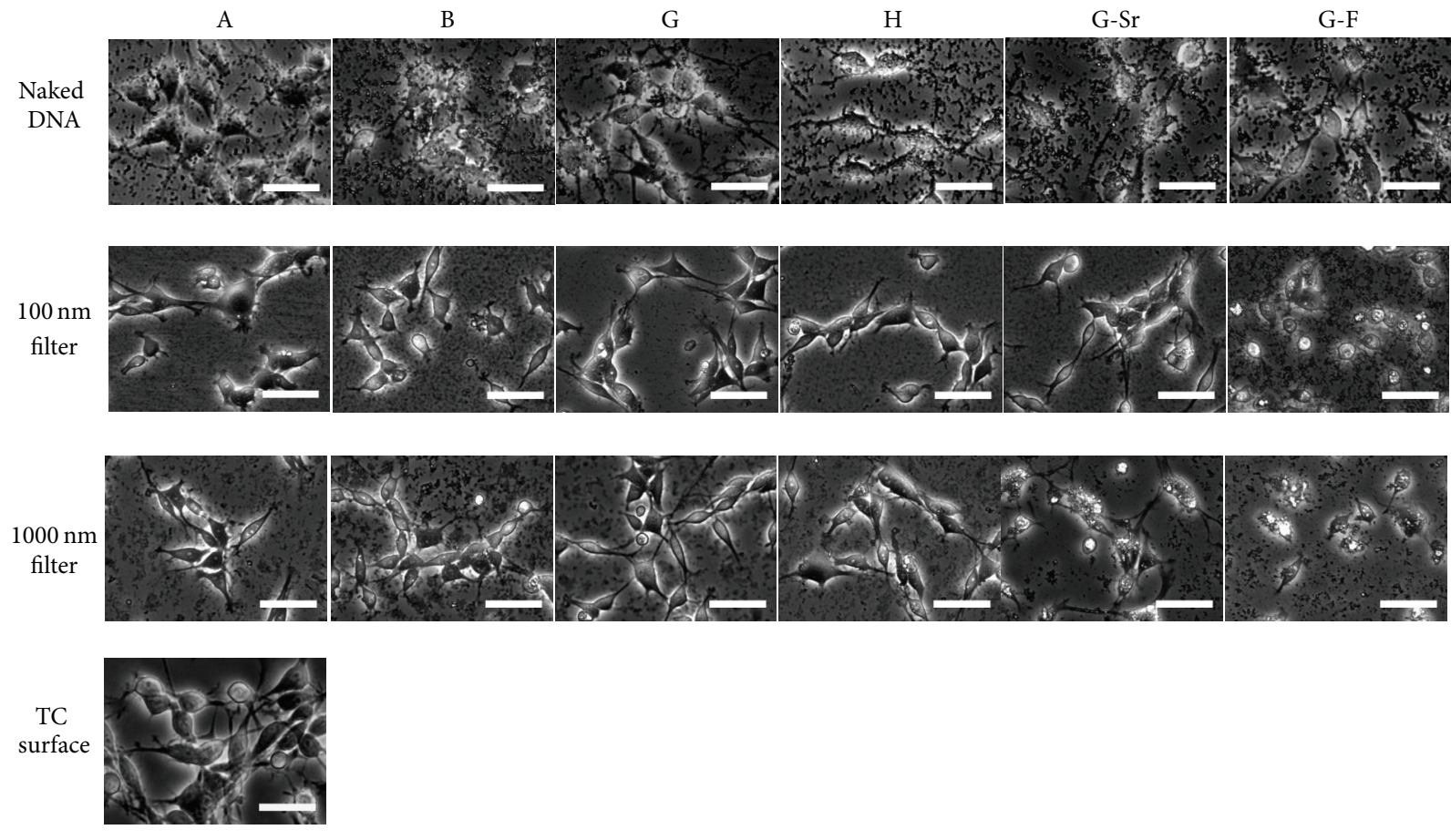

(a)

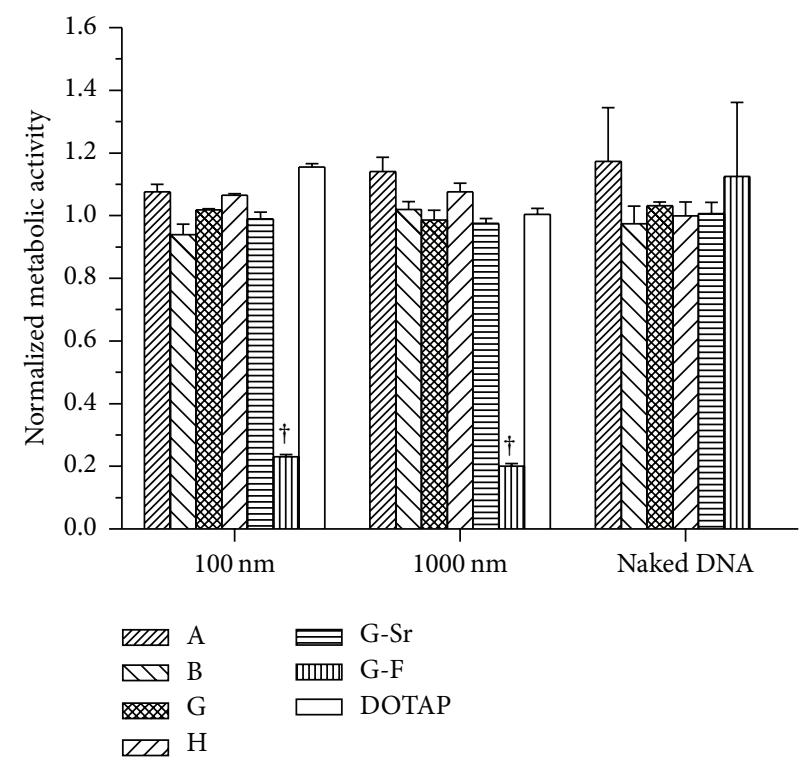

(b)

FIGURE 4: (a) Morphology and (b) the relative metabolic activities of B35 cells cultured on DNA- or lipoplex-nanocomposites formed from the indicated mineralizing formulation. The cells on tissue culture-treated surface (TC surface) were used as the control. The scale bar is $50 \mu \mathrm{m}$. The DNA : DOTAP ratio was 1:12 (w/w). The metabolic activity of cells on surfaces with DNA- or lipoplex-nanocomposites was considered statistically significantly different from that of cells on TC surfaces at ${ }^{\dagger} p<0.001$.

the level of transgene expression was affected by the initial size of liposomes (Figure 6(a)), the DNA to DOTAP ratio (Figure 6(b)) and the duration of complexation (data not shown).

As shown in Figure 6(a), the initial size of DOTAP had a significant effect on the level of transgene expression. Nanocomposites formed with larger liposomes resulted in a statistically significantly higher level of transgene expression than those from smaller liposomes $(p<0.01)$. As demonstrated in Figures 1(b)-1(c), liposomes formed using $1000 \mathrm{~nm}$ filters resulted in larger lipoplexes than using $100 \mathrm{~nm}$ ones. Previous studies demonstrated that lipoplex size has a significant effect on the efficiency of gene transfer [34-36]. Larger lipoplex results in higher gene transfer efficiency because 


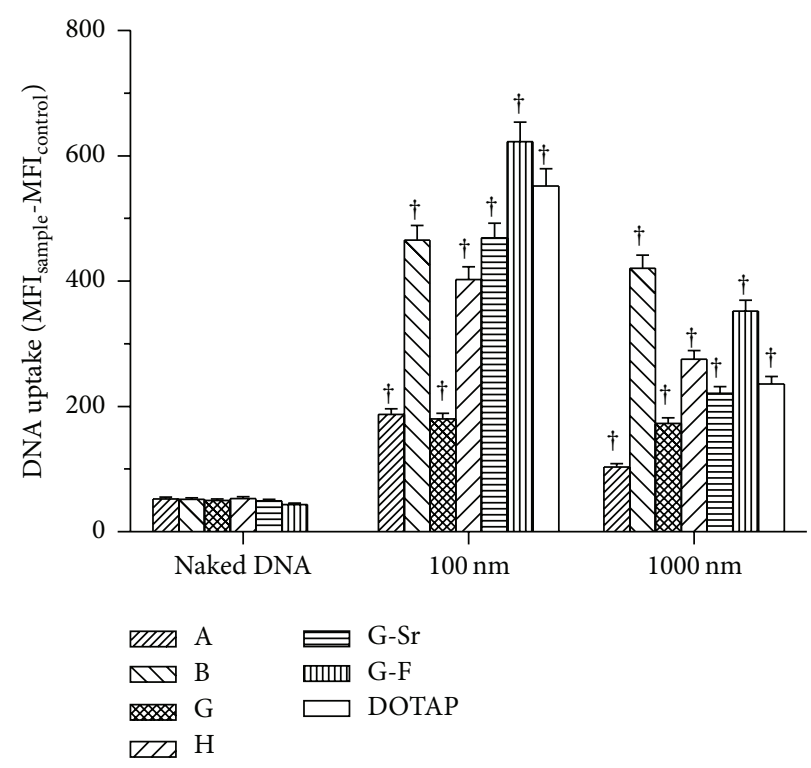

Figure 5: The cellular DNA uptake mediated by surface-induced lipoplex-nanocomposites prepared from mineralizing solutions, A, B, G, H, G-Sr, and G-F. Naked DNA-doped nanocomposites (naked DNA) and free lipoplexes made from DOTAP (DOTAP) were used as controls. The DOTAP liposomes were prepared using freeze-thaw-extrusion method with $100 \mathrm{~nm}$ or $1000 \mathrm{~nm}$ filter. Fluorescein-labeled DNA was used. The ratio of DNA to DOTAP was 1:12 (w/w). Data were shown as means \pm s.e. Statistical significance of differences was determined by the unpaired two-tailed Student's $t$-test. The uptake mediated by lipoplex-nanocomposites was considered statistically significantly different from that by DNA-nanocomposites at ${ }^{\dagger} p<0.001$.

of either larger lipoplexes leading to higher lipoplex-cell uptake and fusion [36] or the formation of larger intracellular vesicles, which are easily disrupted for the release of DNA into cytoplasm [35]. In addition, encapsulation of DNA within larger structures may better shield it from degradation by DNases [37]. The gene transfer in B35 cells mediated by immobilized lipoplexes displayed similar lipoplex sizedependency as free lipoplexes. As we discussed previously (Figure 5), immobilized lipoplexes most likely entered cells in the form of nanocomposites. Upon the entry into cells, nanocomposites were dissolved to release free lipoplexes due to the progressive acidification of phagosomes. As a result, for a given composition of nanocomposites, the level of gene transfer efficiency mediated by lipoplex-nanocomposites derived from different sizes of liposomes may be largely due to the difference in the integrity and release of DNA into cytoplasm instead of cellular uptake.

The gene transfer efficiency by lipoplex-nanocomposites was also dependent on the ratio of DNA to DOTAP (w/w) (Figure 6(b)). As demonstrated in previous studies, for the liposome-mediated gene transfection, the transfection activity peaked at certain charge ratios and decreased with higher or lower charge ratios [38-40]. The immobilized lipoplexes exhibited a similar trend as free lipoplexes. This result demonstrated that the efficiency of gene transfer mediated by lipoplex-nanocomposites is further controlled by the properties of lipoplexes.

Lastly, we examined the gene transfer mediated by DNA/Lipofectamine 2000 nanocomposites. Since we had no information on the composition of lipids, we tested two ratios based on the manufacturer's instructions. The size of liposomes was $114.23 \pm 8.40 \mathrm{~nm}$. The size of the resulting lipoplexes was $496.90 \pm 102.67$ and $220.60 \pm 0.57 \mathrm{~nm}$ for lipoplexes prepared at the DNA to Lipofectamine 2000 ratio $(\mathrm{w} / \mathrm{w})$ of $1: 2$ and $1: 3$, respectively. As shown in Figure 6(c), DNA/Lipofectamine lipoplex-nanocomposites exhibited higher transgene expression than DNA/DOTAP ones, indicating the composition of lipids was an additional parameter to optimize the gene transfer efficiency of lipoplex-nanocomposites. The efficiency of gene transfer by DNA/Lipofectamine lipoplex-nanocomposites was also dependent on the charge ratio and composition of nanocomposites. These results suggest that our observations on DOTAP liposomes can be generalized for other liposomes. The previous study examined one DNA to liposome ratio and one mineralizing solution (simulated body fluid, i.e., mineral solution A) [24]. We cannot make direct comparison to their results. However, both studies demonstrate that immobilized lipoplexes through surface-mediated biomineralization improve the efficiency of gene transfer.

Taken together, our results demonstrated that the immobilization of DNA as lipoplexes through surface-induced biomineralization significantly improved the gene transfer efficiency for neuronal cells. Lipoplexes modulated the morphology and topology of nanocomposites on the surface and resulted in enhanced cellular DNA uptake. The possible pathway by which immobilized lipoplexes mediate the gene transfer was the following: DNA entered cells in the form of nanocomposites composed of biomineral-decorated lipoplexes; in acidic phagosomal compartments, nanocomposites were dissolved and lipoplexes were freed from nanocomposites; subsequently, DNA escaped from phagosomal compartments as free DNA or lipoplexes and then entered nuclei for transcription. Through this pathway, the 


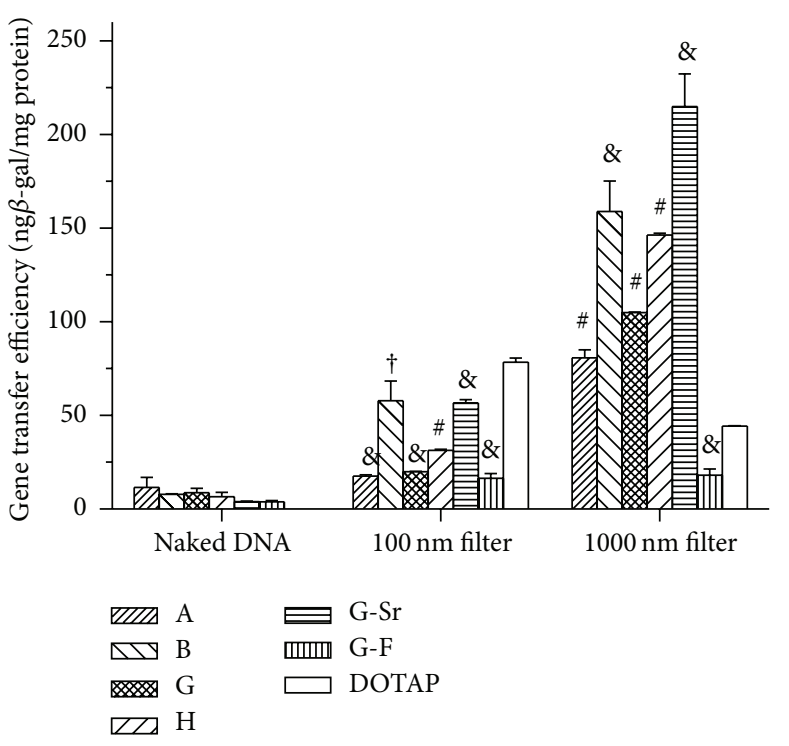

(a)

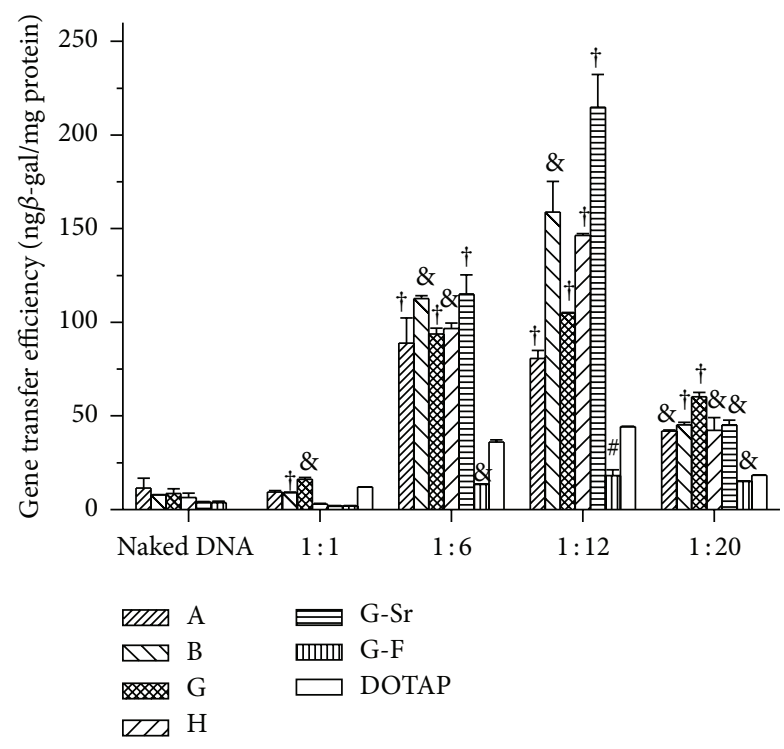

(b)

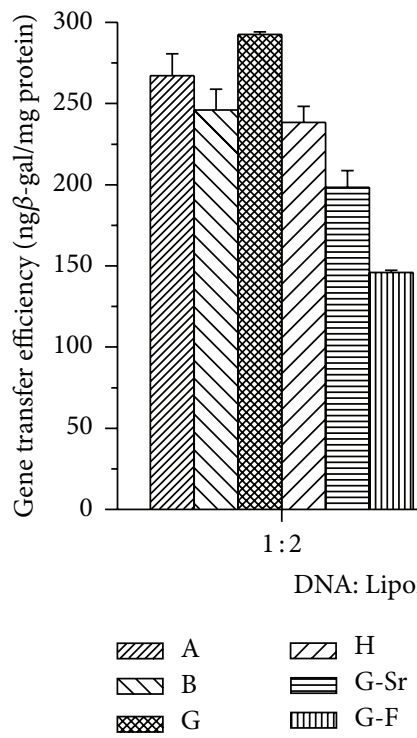

(c)

FIGURE 6: The gene transfer efficiency in B35 cells medicated by surface-induced lipoplex-nanocomposites. (a) The effect of liposome sizes. DNA : DOTAP ratio was $1: 12(\mathrm{w} / \mathrm{w})$; the complexation duration was $15 \mathrm{~min}$. (b) The effect of DNA:DOTAP ratios. The complexation duration was $15 \mathrm{~min}$; the filter size is $1000 \mathrm{~nm}$. The DOTAP liposomes were prepared using freeze-thaw-extrusion method. Naked DNA-doped nanocomposites (naked DNA) and free lipoplexes prepared using DOTAP (DOTAP) were used as controls. (c) The lipoplexes were made from Lipofectamine 2000. The DNA was complexed with Lipofectamine 2000 at different ratios and the complexation duration was 20 min. Data were shown as means \pm s.e. Statistical significance of differences was determined by the unpaired two-tailed Student's $t$-test. The gene transfer efficiency mediated by lipoplex-nanocomposites was considered statistically significantly different from that by DNA-nanocomposites at ${ }^{\#} p<0.05,{ }^{\&} p<0.01$, and ${ }^{\dagger} p<0.001$.

gene transfer efficiency mediated by lipoplex-nanocomposites can be tuned by manipulating both the composition of mineralizing solutions and the physiochemical properties of lipoplexes.

\section{Conclusions}

In this study, we demonstrated that the immobilization of lipoplexes by surface-induced biomineralization modulated the morphology and topology of resulting nanocomposites on the surfaces of biomaterials and thus the internalization of DNA to cells. As a result, the cellular uptake of DNA and transgene expression were greatly enhanced in neuronal cells compared to immobilized naked DNA. The gene transfer efficiency can be tuned by the composition of mineralizing solutions, the initial size of the liposomes, and the ratio of liposomes to DNA (w/w). The surface-induced biomineralization represents a flexible approach to immobilizing DNA 
in the form of both DNA and lipoplexes onto biomaterial surfaces. In our studies, we did not alter the process of mineralization but only replaced naked DNA with lipoplexes. Therefore, all the processes developed previously can be adapted for lipoplexes.

\section{Conflict of Interests}

The authors declare that there is no conflict of interests regarding the publication of this paper.

\section{Acknowledgments}

This work was supported by the Grant EB007494 from the National Institutes of Health and by the National Science Foundation CAREER Award given to H. Shen. AFM was provided by NanoTech User Facility at University of Washington.

\section{References}

[1] Z. Bengali, A. K. Pannier, T. Segura et al., "Gene delivery through cell culture substrate adsorbed DNA complexes," Biotechnology and Bioengineering, vol. 90, no. 3, pp. 290-302, 2005.

[2] T. Segura and L. D. Shea, "Surface-tethered DNA complexes for enhanced gene delivery," Bioconjugate Chemistry, vol. 13, no. 3, pp. 621-629, 2002.

[3] L. De Laporte and L. D. Shea, "Matrices and scaffolds for DNA delivery in tissue engineering," Advanced Drug Delivery Reviews, vol. 59, no. 4-5, pp. 292-307, 2007.

[4] M. D. Kofron and C. T. Laurencin, "Development of a calcium phosphate co-precipitate/poly(lactide-co-glycolide) DNA delivery system: release kinetics and cellular transfection studies," Biomaterials, vol. 25, no. 13, pp. 2637-2643, 2004.

[5] M. Chatzinikolaidou, C. Hadjicharalambous, V. Sokolova, D. Kozlova, and M. Epple, "Induction of osteogenic differentiation as a result of BMP-7 plasmid DNA delivery using calcium phosphate nanoparticles as carriers," Journal of Tissue Engineering and Regenerative Medicine, vol. 8, p. 417, 2014.

[6] A. U. Bielinska, A. Yen, H. L. Wu et al., "Application of membrane-based dendrimer/DNA complexes for solid phase transfection in vitro and in vivo," Biomaterials, vol. 21, no. 9, pp. 877887,2000

[7] A. Lakshminarayanan, V. K. Ravi, R. Tatineni et al., "Efficient dendrimer-DNA complexation and gene delivery vector properties of nitrogen-core poly(propyl ether imine) dendrimer in mammalian cells," Bioconjugate Chemistry, vol. 24, no. 9, pp. 1612-1623, 2013.

[8] P. T. Wong, K. Tang, A. Coulter, S. Tang, J. R. Baker Jr., and S. K. Choi, "Multivalent dendrimer vectors with DNA intercalation motifs for gene delivery," Biomacromolecules, vol. 15, no. 11, pp. 4134-4145, 2014.

[9] J.-H. Jang, Z. Bengali, T. L. Houchin, and L. D. Shea, "Surface adsorption of DNA to tissue engineering scaffolds for efficient gene delivery," Journal of Biomedical Materials Research Part A, vol. 77, no. 1, pp. 50-58, 2006.

[10] Z. Bengali, J. C. Rea, and L. D. Shea, "Gene expression and internalization following vector adsorption to immobilized proteins: dependence on protein identity and density," Journal of Gene Medicine, vol. 9, no. 8, pp. 668-678, 2007.
[11] L. De Laporte, A. L. Yan, and L. D. Shea, "Local gene delivery from ECM-coated poly(lactide-co-glycolide) multiple channel bridges after spinal cord injury," Biomaterials, vol. 30, no. 12, pp. 2361-2368, 2009.

[12] A. Ewe, A. Schaper, S. Barnert et al., "Storage stability of optimal liposome-polyethylenimine complexes (lipopolyplexes) for DNA or siRNA delivery," Acta Biomaterialia, vol. 10, no. 6, pp. 2663-2673, 2014.

[13] R. M. Levine, T. R. Pearce, M. Adil, and E. Kokkoli, "Preparation and characterization of liposome-encapsulated plasmid DNA for gene delivery," Langmuir, vol. 29, no. 29, pp. 9208-9215, 2013.

[14] T. Segura, P. H. Chung, and L. D. Shea, "DNA delivery from hyaluronic acid-collagen hydrogels via a substrate-mediated approach," Biomaterials, vol. 26, no. 13, pp. 1575-1584, 2005.

[15] H. Shen, J. Tan, and W. M. Saltzman, "Surface-mediated gene transfer from nanocomposites of controlled texture," Nature Materials, vol. 3, no. 8, pp. 569-574, 2004.

[16] A. Oyane, H. Tsurushima, and A. Ito, "Novel gene-transferring scaffolds having a cell adhesion molecule-DNA-apatite nanocomposite surface," Gene Therapy, vol. 14, no. 24, pp. 1750-1753, 2007.

[17] B. Sun, K. K. Tran, and H. Shen, "Enabling customization of non-viral gene delivery systems for individual cell types by surface-induced mineralization," Biomaterials, vol. 30, no. 31, pp. 6386-6393, 2009.

[18] B. Sun, M. Yi, C. C. Yacoob, H. T. Nguyen, and H. Shen, "Effect of surface chemistry on gene transfer efficiency mediated by surface-induced DNA-doped nanocomposites," Acta Biomaterialia, vol. 8, no. 3, pp. 1109-1116, 2012.

[19] J. O. Rädler, I. Koltover, T. Salditt, and C. R. Safinya, "Structure of DNA-cationic liposome complexes: DNA intercalation in multilamellar membranes in distinct interhelical packing regimes," Science, vol. 275, no. 5301, pp. 810-814, 1997.

[20] I. Koltover, T. Salditt, J. O. Rädler, and C. R. Safinya, "An inverted hexagonal phase of cationic liposome-DNA complexes related to DNA release and delivery," Science, vol. 281, no. 5373, pp. 7881, 1998.

[21] B. Sternberg, F. L. Sorgi, and L. Huang, "New structures in complex formation between DNA and cationic liposomes visualized by freeze-fracture electron microscopy," FEBS Letters, vol. 356, no. 2-3, pp. 361-366, 1994.

[22] D. D. Archibald and S. Mann, "Template mineralization of selfassembled anisotropic lipid microstructures," Nature, vol. 364, no. 6436, pp. 430-433, 1993.

[23] S. R. Letellier, M. J. Lochhead, A. A. Campbell, and V. Vogel, "Oriented growth of calcium oxalate monohydrate crystals beneath phospholipid monolayers," Biochimica et Biophysica Acta-General Subjects, vol. 1380, no. 1, pp. 31-45, 1998.

[24] L. N. Luong, K. M. McFalls, and D. H. Kohn, "Gene delivery via DNA incorporation within a biomimetic apatite coating," Biomaterials, vol. 30, no. 36, pp. 6996-7004, 2009.

[25] J. M. García-Castellano, P. Díaz-Herrera, and J. A. Morcuende, "Is bone a target-tissue for the nervous system? New advances on the understanding of their interactions," Iowa Orthopaedic Journal, vol. 20, pp. 49-58, 2000.

[26] Y. Zhang, E. L. Bradshaw-Pierce, A. Delille, D. L. Gustafson, and T. J. Anchordoquy, "In vivo comparative study of lipid/DNA complexes with different in vitro serum stability: effects on biodistribution and tumor accumulation," Journal of Pharmaceutical Sciences, vol. 97, no. 1, pp. 237-250, 2008. 
[27] L. Wang and R. C. MacDonald, "Synergistic effect between components of mixtures of cationic amphipaths in transfection of primary endothelial cells," Molecular Pharmaceutics, vol. 4, no. 4, pp. 615-623, 2007.

[28] K. Tabatt, C. Kneuer, M. Sameti et al., "Transfection with different colloidal systems: comparison of solid lipid nanoparticles and liposomes," Journal of Controlled Release, vol. 97, no. 2, pp. 321-332, 2004.

[29] L. G. Morin, "Direct colorimetric determination of serumcalcium with ortho cresolphthalein complexon," American Journal of Clinical Pathology, vol. 61, pp. 114-117, 1974.

[30] M. Traïkia, D. E. Warschawski, M. Recouvreur, J. Cartaud, and P. F. Devaux, "Formation of unilamellar vesicles by repetitive freeze-thaw cycles: characterization by electron microscopy and ${ }^{31}$ P-nuclear magnetic resonance," European Biophysics Journal, vol. 29, no. 3, pp. 184-195, 2000.

[31] D. Slamenova, K. Ruppova, A. Gabelpva, and L. Wsolova, "Evaluation of mutagenic and cytotoxic effects of sodium fluoride on mammalian cells influenced by an acid environment," Cell Biology and Toxicology, vol. 12, no. 1, pp. 11-17, 1996.

[32] N. Pereira-Rodrigues, P.-E. Poleni, D. Guimard, Y. Arakawa, Y. Sakai, and T. Fujii, "Modulation of Hepatocarcinoma cell morphology and activity by parylene-C coating on PDMS," PLoS ONE, vol. 5, no. 3, Article ID e9667, 2010.

[33] L. De Bartolo, S. Morelli, A. Bader, and E. Drioli, "Evaluation of cell behaviour related to physico-chemical properties of polymeric membranes to be used in bioartificial organs," Biomaterials, vol. 23, no. 12, pp. 2485-2497, 2002.

[34] A. Masotti, G. Mossa, C. Cametti et al., "Comparison of different commercially available cationic liposome-DNA lipoplexes: parameters influencing toxicity and transfection efficiency," Colloids and Surfaces B: Biointerfaces, vol. 68, no. 2, pp. 136-144, 2009.

[35] M. R. Almofti, H. Harashima, Y. Shinohara, A. Almofti, W. H. Li, and H. Kiwada, "Lipoplex size determines lipofection efficiency with or without serum," Molecular Membrane Biology, vol. 20, no. 1, pp. 35-43, 2003.

[36] P. C. Ross and S. W. Hui, "Lipoplex size is a major determinant of in vitro lipofection efficiency," Gene Therapy, vol. 6, no. 4, pp. 651-659, 1999.

[37] Y. Liu, L. C. Mounkes, H. D. Liggitt et al., "Factors influencing the efficiency of cationic liposome-mediated intravenous gene delivery," Nature Biotechnology, vol. 15, no. 2, pp. 167-173, 1997.

[38] Y. Xu, S.-W. Hui, P. Frederik, and F. C. Szoka Jr., "Physicochemical characterization and purification of cationic lipoplexes," Biophysical Journal, vol. 77, no. 1, pp. 341-353, 1999.

[39] D. L. Reimer, S. Kong, and M. B. Bally, "Analysis of cationic liposome-mediated interactions of plasmid dna with murine and human melanoma cells in vitro," Journal of Biological Chemistry, vol. 272, no. 31, pp. 19480-19487, 1997.

[40] E. R. Lee, J. Marshall, C. S. Siegel et al., "Detailed analysis of structures and formulations of cationic lipids for efficient gene transfer to the lung," Human Gene Therapy, vol. 7, no. 14, pp. 1701-1717, 1996. 

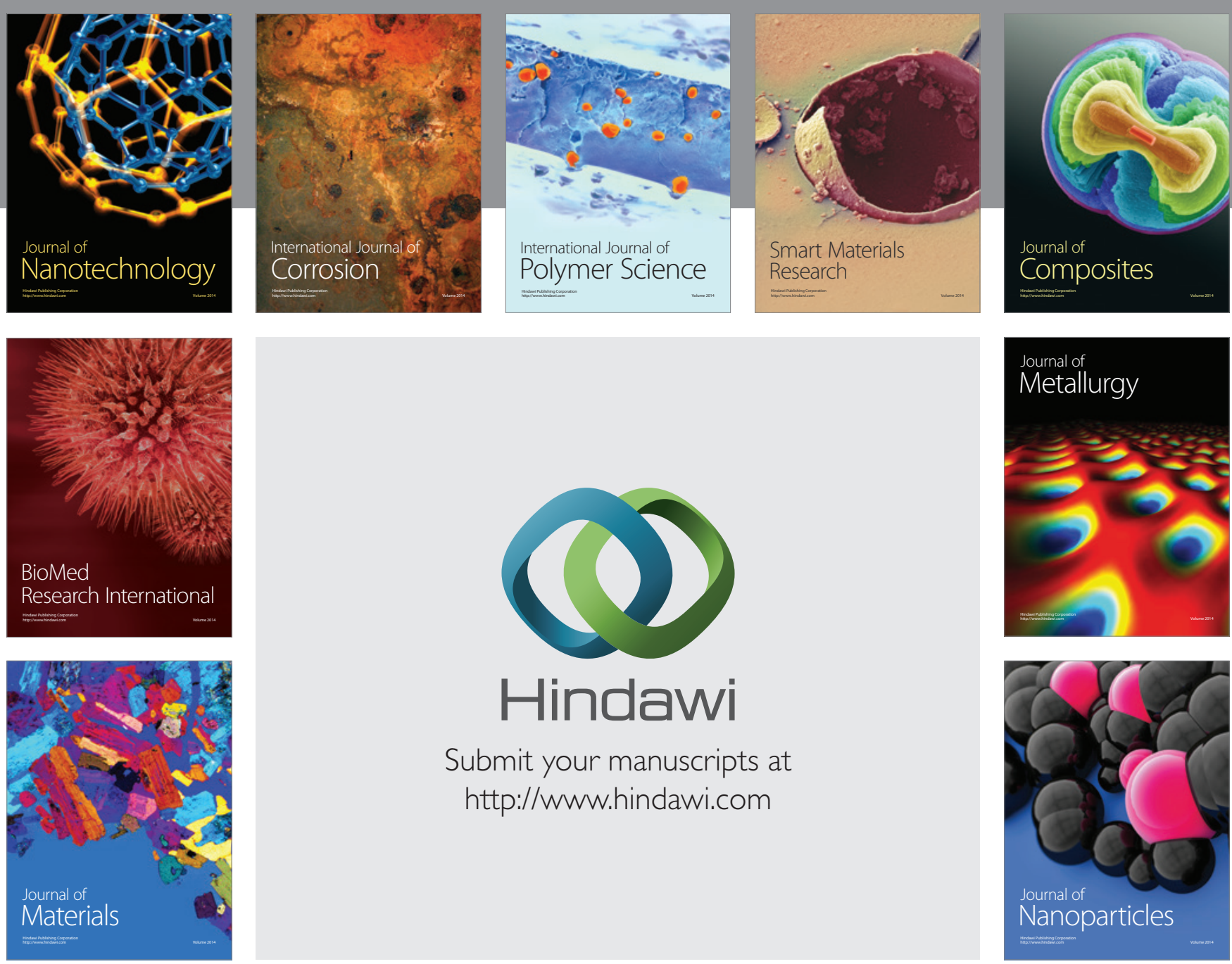

Submit your manuscripts at http://www.hindawi.com
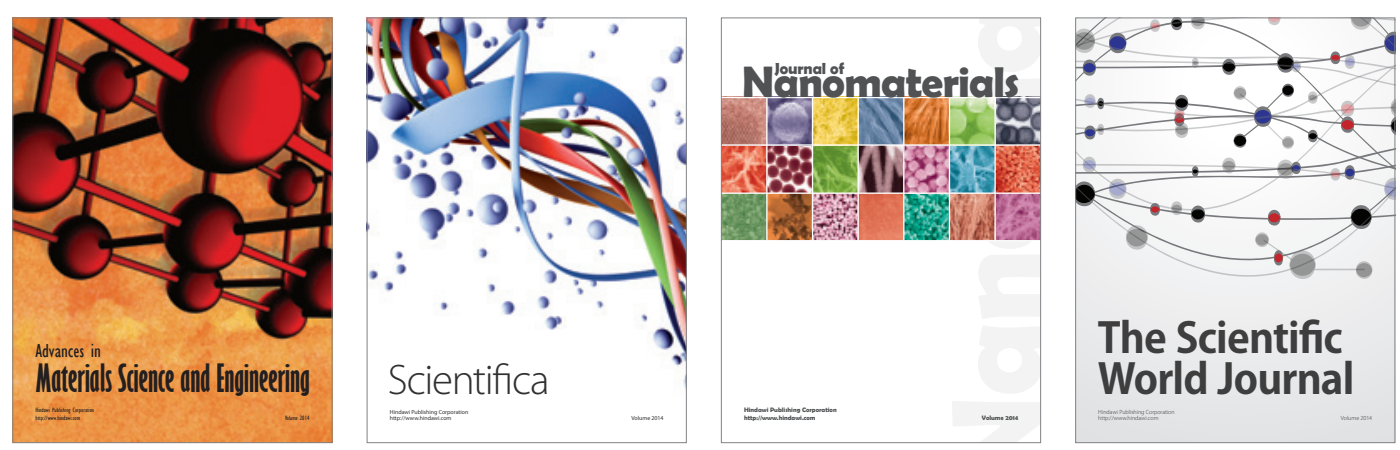

\section{The Scientific World Journal}
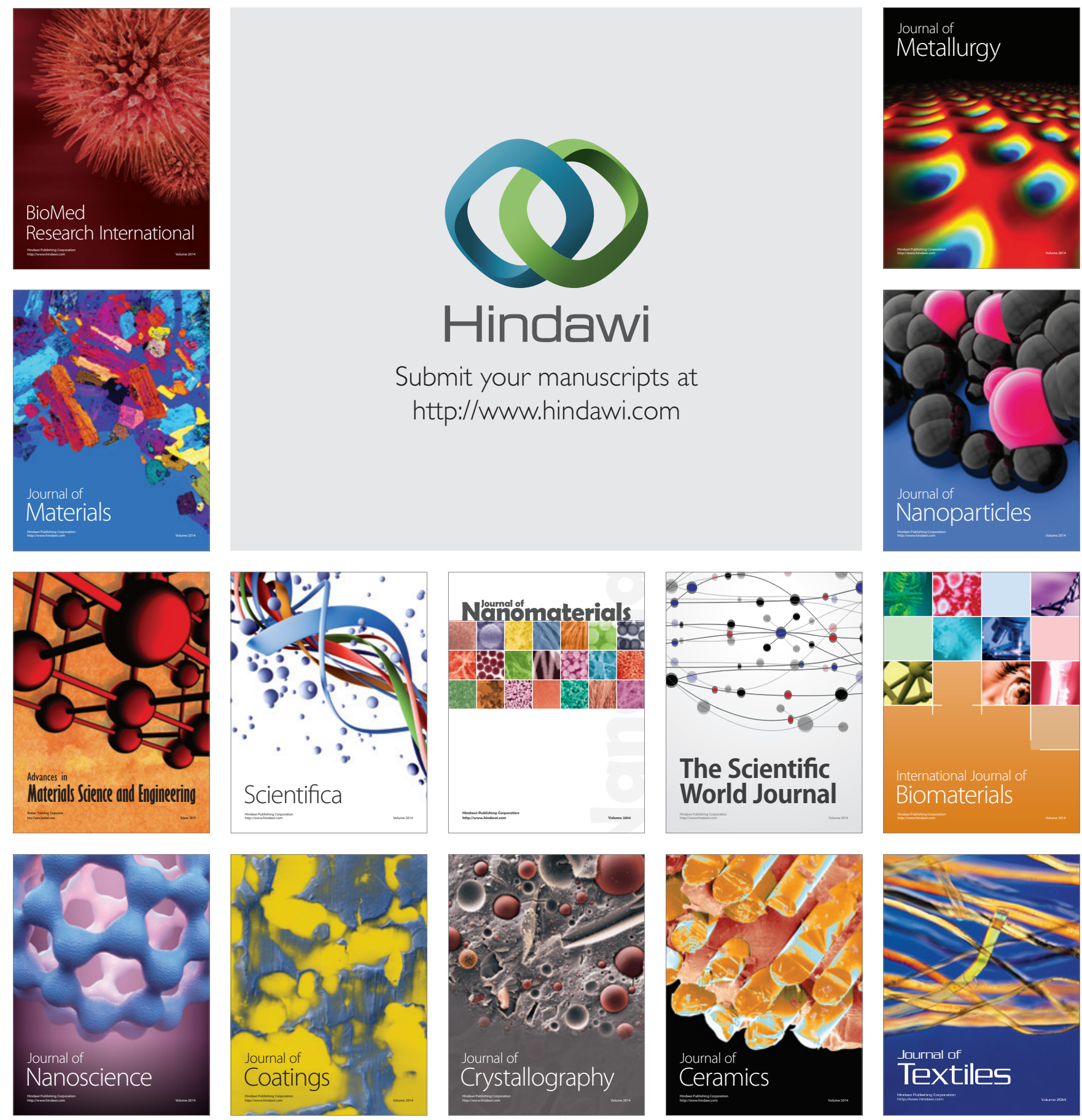